\title{
The Estimation of Property Tax Capitalisation in the Korean Taxation Context
}

\author{
Hyung Min $\mathrm{Kim}^{1 *}$, Kyoung-Seok $\mathrm{Jang}^{2}$, Youn-Kyoung $\mathrm{Hur}^{3}$ \\ ${ }^{1}$ Department of Urban Planning and Design, Xianjiaotong-Liverpool University, Suzhou, China \\ ${ }^{2}$ Office of Economic and Industrial Research, National Assembly Research Service, Seoul, Korea \\ ${ }^{3}$ Construction Economy Division, Construction and Economy Research Institute of Korea, Seoul, Korea \\ Email: "hm.kim@xjtlu.edu.cn, jangks@assembly.go.kr, ykhur@cerik.re.kr
}

Received August 12 $2^{\text {th }}, 2013$; revised September $15^{\text {th }}, 2013$; accepted September $23^{\text {rd }}, 2013$

\begin{abstract}
Copyright (C) 2013 Hyung Min Kim et al. This is an open access article distributed under the Creative Commons Attribution License, which permits unrestricted use, distribution, and reproduction in any medium, provided the original work is properly cited.
\end{abstract}

\begin{abstract}
The difference between public services and property tax rates is capitalised into home values. The aim of this research is to estimate the property tax capitalisation rate under a different taxation context of Korea, using a repeat sales method with short-term data on housing prices and estimated tax payments. In the operation of the property taxation, there is complexity that needs to be considered in the estimation of the property tax capitalisation rate. In this research, 32,101 apartment samples in Seoul are used for the analysis. Given these unique institutional circumstances, as a result of the analysis, the property tax capitalisation rate in Seoul was between $73.7 \%$ and $82.8 \%$ in the analysis periods.
\end{abstract}

Keywords: Housing Prices; Property Tax; Gross Real Estate Tax (GRET); Capitalisation; Repeat Sales Model

\section{Introduction}

The difference between public services and property tax rates is capitalised in home values. This phenomenon is called a capitalisation effect (Yinger et al., 1988; Rosen \& Gayer, 2007). Higher property tax payments lead to lower house values if all else being equal. Theoretically, housing prices drop by the discounted present value of property tax payments when the property taxes are imposed. This is called full or complete capitalisation. However, in the extensive study of Yinger et al. (1988), property taxes were partially capitalised. In spite of a simple concept of property tax capitalisation, it is challenging to estimate the degree of capitalisation (Yinger et al., 1988).

Different taxation policy contexts require different analysis methods. During the early 2000s, housing prices increased drastically in a selected few areas in Korea. According to a housing price index, housing prices in Seoul increased approximately $50 \%$ over the three years in the early 2000 s. In response to the changes in the housing market, the Korean government utilised property taxation as a tool to stabilise housing prices and to improve housing affordability. The government announced more than 30 policies on property markets during the period 2003-7 (Jang, 2010: pp. 274-355). Nevertheless, little has been studied about the influence of the reinforced property taxes on housing prices in Korea.

Thus, the aim of this research is to estimate the property tax capitalisation rate under a different taxation context of Korea, using a repeat sales method with short-term data on housing prices and estimated tax payments. This study sheds light on the presence of the property tax capitalisation effect and proposes a new method to estimate that effect.

\footnotetext{
*Corresponding author.
}

\section{Institutional Context}

The Korean government has three hierarchies: the central government, metropolitan governments (si/do, e.g. Seoul, Busan or Gyeonggi), and local governments (si/gun/gu). Each government levies property taxes, respectively. In order to calculate property tax rates precisely, this section reviews the structure of property taxation in Korea currently being operated in the three levels.

Firstly, there are many types of property taxes as a form of a surtax imposed by different levels of governments. These taxes include "Property Tax"1 and "Gross Real Estate Tax (hereafter GRET)" and there are other taxes, based on the same property, such as "City Planning Tax", "Local Education Tax", "Facilities Tax", and "Special Tax for Rural Development". These taxes should be regarded as one of the property taxes because they are all levied to the same property using the same paying method. For example, when tax payers pay for the "Property Tax" to the local governments, they also have to pay for the "Facilities Tax" to the metropolitan government with the same tax bill. The "Local Education Tax" is additionally imposed to the owner with $20 \%$ of property tax payments. These taxes are included in one tax bill so that the governments may collect taxes easily. The collected money is distributed to each government. Likewise, the "Special Tax for Rural Development" is the surtax of $20 \%$ of the GRET. The GRET is imposed to expensive housing by the central government in order to stabilise housing prices, to recoup capital gains and to contribute to ba-

${ }^{1}$ In this study, the property tax as a general term is different from the "Property Tax" as one sort of property taxes in Korea; the property tax includes taxes based on land and property.

${ }^{2}$ City Planning Tax was incorporated into the part of "Property Tax" in 2011. 
lanced development between regions. Accordingly, it is easy to underestimate effective property tax rates when tax payers only consider the legal tax rate described in the Local Tax Act. To be precise, all these taxes, thus, need to be regarded as the property taxes.

Secondly, the Korean property taxation is progressive by values. Higher tax rates are applied to expensive houses, while lower tax rates, inexpensive ones. Progressiveness was strengthened due to the enforcement of the "Gross Real Estate Tax Act" in 2006. For houses below 40 million $\mathrm{WON}^{3}$, their "Property Tax" rate is only $0.15 \%$. However, for houses more expensive than 600 million WON, their "Property Tax" rate becomes $1 \%$. If the price is over 2 billion WON, the owner has to pay $2 \%$ of assessed housing prices. Table 1 summarises the details of tax rates by housing price bands.

Thirdly, local governments have a limited influence in the decision of property tax rates. For the purpose of equity between regions, the "Local Tax Act" bans local governments from changing tax rates. The elastic taxation meant that local governments had the authority to adopt a different tax rate within $50 \%$ of flexibility; the elastic tax rates were only operated in 2005 and 2006. During these periods, a few local governments adopted lower property tax rates than standard tax rates presented in the "Local Tax Act". However, equity was considered significant and the implementation of elastic taxation ended in 2006. Basically, the central and metropolitan government support the deficit after local governments finance local taxes at given property tax rates. So, there is a discrepancy between burdens of tax payers and benefits from the local governments. Even though owners of expensive properties pay for a large amount of property taxes on a higher tax rate, they benefit from public services similar to those who pay less due to an inflexible tax rate system discussed above.

Besides, additional complexity exists in the taxation. A tax payment-cap policy is in operation. The purpose of this policy is to prevent a rapid increase in tax payments caused from sudden changes in the real estate market. For example, a property tax payment should not exceed over $105 \%$ of the last payment when the price of the property is within 300 million WON, $110 \%$ for its price is laid between 300 and 600 million WON, and $150 \%$, over 600 million WON. In addition, the aggregate amount of the "Property Tax" and the GRET should not exceed three times of the property tax payments in relation to the corresponding period last year.

This complexity under Korean taxation contexts creates difficulties in estimating the property capitalisation rate. Thus, the principle of the repeat sales model is used to estimate the property taxation capitalisation.

\section{Data and Method}

\section{Data}

The Korean central government assesses housing prices of all housing in Korea for tax purpose on a yearly basis viaa government agency-Korea Appraisal Board (KAB). The appraised prices make it possible to calculate the amount of individual property tax payments.

The unit of the analysis in this research is an individual apartment (high-rise condominium). Extensive data for three years about housing (appraised) prices between 2006 and 2008

${ }^{3}$ US $\$ 1=956$ WON in 2006, 1103 WON in 2008.
Table 1.

Legal tax rates and tax base in Korea.

\begin{tabular}{|c|c|c|c|}
\hline Tax title & $\begin{array}{l}\text { Housing prices } \\
\text { (million WON) }\end{array}$ & $\begin{array}{c}\text { Tax rate } \\
(\%)\end{array}$ & Tax base \\
\hline \multirow{3}{*}{$\begin{array}{l}\text { Property } \\
\text { Tax }\end{array}$} & Below 40 & 0.15 & \multirow{3}{*}{$\begin{array}{l}\text { Assessed housing } \\
\text { prices }\end{array}$} \\
\hline & $40-100$ & 0.3 & \\
\hline & Over 100 & 0.5 & \\
\hline \multirow{4}{*}{$\begin{array}{l}\text { Gross Real } \\
\text { Estate Tax }\end{array}$} & Below 300 & 1.0 & \multirow{4}{*}{$\begin{array}{l}\text { Assessed housing } \\
\text { prices subtracted } \\
600 \text { million WON }\end{array}$} \\
\hline & $300-1400$ & 1.5 & \\
\hline & $1400-10,000$ & 2.0 & \\
\hline & 10,000 & 3.0 & \\
\hline \multicolumn{2}{|c|}{ City Planning Tax } & 0.15 & The same to the property tax \\
\hline \multicolumn{2}{|c|}{ Local Education Tax } & 20 & The amount of property tax \\
\hline \multicolumn{2}{|c|}{$\begin{array}{l}\text { Special Tax for Rural } \\
\text { Development }\end{array}$} & 20 & $\begin{array}{l}\text { The amount of } \\
\text { global real estate tax }\end{array}$ \\
\hline
\end{tabular}

Source: The Local Tax Act and Gross Real Estate Tax Act.

was used for this research. A sample consists of 32,101 apartments, which account for $2.6 \%$ of total apartment stocks in Seoul (see Table 2). Apartment is a major housing type in Seoul, accounting for $54.2 \%$ of the housing stock (Census in 2005). Almost new housing construction is composed of apartments, for example, $76.5 \%$ in 2006 , and $100 \%$ of housing renewal projects were a form of high-rise apartments (Ha, 2010). Thus, the sample of this research is large enough to represent Seoul's housing market.

The average housing price was 222,375 thousand WON in 2006, 279,042 thousand WON in 2007 (a 25.5\% increase in relation to 2006), and 290,946 thousand WON in 2008 (a 4.3\% increase in relation to 2007). More details are in Appendix.

To calculate the amount of tax payments and effective tax rates, following four factors were considered in the Korean context: appraised apartment prices, tax-rate bands, the elastic tax rates in 2006 , and the property tax payment cap ${ }^{4}$. These factors made the amount of property tax payments change every year. The effective tax rate is house's property tax payment divided by its market value (Yinger et al., 1988). The summary of calculated tax payment and their effective tax rates are presented in Table 3.

Based on aggregated tax payments and appraised prices, effective property tax rates were 2.059 mill in $2006,1.990$ mill in 2007, and 2.139 mill in 2008, respectively.

\section{Methodology}

This study takes advantage of the principle of a repeat sales model. The repeat sales model was developed by Bailey et al. (1963). Then, Case \& Shiller (1987) used this model to estimate variations in housing prices and to create an housing price in-

\footnotetext{
${ }^{4}$ The "Local Tax Act" bans local governments from elastic tax rates across regions for the purpose of equity. The elastic taxation was that local governments had the authority to adopt a different tax rate within fifty per cent of flexibility; the elastic tax rates were only operated in 2005 and 2006 During this period, a few local governments adopted lower property tax rates than standard tax rates presented in the "Local Tax Act". The central and metropolitan government support the deficit after local governments finance local taxes.
} 
Table 2.

Statistics of summary ${ }^{1}$.

\begin{tabular}{ccccc}
\hline Variables & Mean & $\begin{array}{c}\text { Standard } \\
\text { deviation }\end{array}$ & Minimum & Maximum \\
\hline The age of house in 2006 & 11.86 & 7.23 & 0.00 & 39.00 \\
House net area $\left(\mathrm{m}^{2}\right)$ & 72.70 & 24.29 & 23.70 & 244.97 \\
Housing price in $2006^{2}$ & 222.38 & 164.21 & 38.00 & 2780.00 \\
Housing price in $2007^{2}$ & 279.04 & 222.08 & 39.00 & 3856.00 \\
Housing price in $2008^{2}$ & 290.95 & 208.57 & 48.00 & 3480.00 \\
\hline
\end{tabular}

${ }^{1}$ Number of samples is $32101 ;{ }^{2}$ Million WON.

Table 3.

Estimated effective tax rates and tax payments by districts.

\begin{tabular}{|c|c|c|c|c|c|c|}
\hline & \multicolumn{3}{|c|}{ Tax rates (mill) } & \multicolumn{3}{|c|}{$\begin{array}{l}\text { Tax payment per house } \\
\text { (thousand WON) }\end{array}$} \\
\hline & 2006 & 2007 & 2008 & 2006 & 2007 & 2008 \\
\hline Gangnam & 2.243 & 2.483 & 3.085 & 1360 & 2084 & 2660 \\
\hline Gangdong & 2.189 & 2.078 & 2.286 & 616 & 754 & 827 \\
\hline Gangbuk & 1.814 & 1.704 & 1.662 & 283 & 314 & 369 \\
\hline Gangseo & 1.830 & 1.643 & 1.769 & 312 & 386 & 424 \\
\hline Gwanak & 1.968 & 1.840 & 1.902 & 373 & 417 & 466 \\
\hline Gwangjin & 2.517 & 2.318 & 2.535 & 739 & 914 & 1018 \\
\hline Guro & 1.841 & 1.714 & 1.727 & 299 & 338 & 385 \\
\hline Geumcheon & 2.106 & 1.967 & 2.014 & 337 & 370 & 409 \\
\hline Nowon & 1.743 & 1.603 & 1.613 & 256 & 291 & 336 \\
\hline Dobong & 2.058 & 1.944 & 1.926 & 325 & 357 & 406 \\
\hline Dongdaemun & 2.059 & 1.997 & 2.020 & 424 & 459 & 517 \\
\hline Dongjak & 2.181 & 1.981 & 2.091 & 538 & 629 & 714 \\
\hline Mapo & 2.184 & 2.017 & 2.154 & 548 & 638 & 715 \\
\hline Seodaemun & 2.310 & 2.219 & 2.250 & 454 & 490 & 546 \\
\hline Seocho & 2.643 & 3.057 & 3.795 & 1,439 & 2285 & 2845 \\
\hline Seongdong & 2.427 & 2.274 & 2.397 & 643 & 729 & 808 \\
\hline Seongbuk & 1.993 & 1.928 & 1.945 & 386 & 419 & 473 \\
\hline Songpa & 2.190 & 2.314 & 2.774 & 969 & 1414 & 1700 \\
\hline Yangcheon & 1.991 & 1.870 & 2.166 & 545 & 825 & 954 \\
\hline Yeongdeungpo & 2.129 & 2.058 & 2.210 & 585 & 769 & 890 \\
\hline Yongsan & 2.658 & 2.828 & 3.196 & 1248 & 1918 & 2334 \\
\hline Eunpyeong & 2.139 & 2.030 & 2.056 & 352 & 379 & 421 \\
\hline Jongno & 1.999 & 1.965 & 2.014 & 428 & 490 & 565 \\
\hline Jung & 1.959 & 1.902 & 2.079 & 558 & 652 & 719 \\
\hline Jungnang & 2.062 & 1.946 & 1.974 & 311 & 340 & 378 \\
\hline $\begin{array}{l}\text { Average } \\
\text { (Seoul) }\end{array}$ & 2.059 & 1.990 & 2.139 & 534 & 698 & 808 \\
\hline
\end{tabular}

Note: Mill is $1 / 1000$. dex using transaction prices. Since Bailey et al. and Case \& Shiller, the repeat sales model has been widely used in generating a housing price index and understanding property markets (McMillen, 2008). The principle of the repeat sales model is that, when one house is transacted, the price matches to the previous transaction price of the same house so that the difference between the two prices can be measured precisely. The changes in housing prices are estimated by a regression analysis. The rationale of this matching is to remove any expected biases. Every single house has its unique locational and structural characteristics. Accordingly, only when the house is compared to the same house without any structural alterations, can real changes of housing prices be correctly measured.

The repeat sales model adds time-variables to the hedonic price model used for a cross-sectional analysis. As the same house is compared in calculation of housing price changes, the repeat sales model rules out the effects of other variables, such as lot size, bedrooms, toilets, and garages, as long as the house was not renovated between the two transaction periods.

In the model of the initial repeat sales model by Bailey et al. (1963), a natural log was taken to calculate the changing rates of housing prices. The natural log makes left-sides directly a variation rate in housing prices. $P_{f}$ is the first transaction and $P_{s}$ is the second one in Equations (1) and (2) (Choi et al., 2010). $\gamma_{f}$ and $\gamma_{s}$ are the intercept composed of macro-economic factors, housing preferences and other factors that can influence housing prices.

$$
\begin{aligned}
& \operatorname{In} P_{s}=\sum_{i=1}^{K} \beta_{i, s} \operatorname{In} X_{i, s}+\gamma_{s}+\varepsilon_{s} \\
& \operatorname{In} P_{f}=\sum_{i=1}^{K} \beta_{i, f} \operatorname{In} X_{i, f}+\gamma_{f}+\varepsilon_{f}
\end{aligned}
$$

where $X_{i}$ is characteristic of the house.

$\beta_{i}$ is coefficient.

$\varepsilon_{s}$ and $\varepsilon_{f}$ are error terms.

As Equation (1) subtracts Equation (2), the equation is simplified to conduct a regression analysis. In Equation (3), the explanatory variables in a general hedonic price model are deleted.

$$
\operatorname{In} \frac{P_{s}}{P_{f}}=\sum_{t=1}^{T} \beta_{t} D_{t}+\mathrm{v}
$$

where, $\beta_{1}=0, \mathrm{v}=e_{s}-e_{f}$.

The left side is the rate of variations in housing prices; all individual housing characteristics are removed in the right side. This is the most advantageous feature in the repeat sales model simplifying model specification. $D_{t}$ in Equation (3) is a dummy variable. It becomes one when transaction occurs, otherwise zero. $\beta_{t}$ is the coefficient to be estimated by conducting a regression analysis. $\beta_{t}$ can be transformed to a housing price in$\mathrm{dex}^{5}$.

McMillen (2003) and Kim \& Lee (2004, 2005) modify the repeat sales model. They divide variables into time-varying variables and time-fixed variables to discover how influence of the time-varying variables has changed, by estimating the coefficient of the time-varying variables, where time-fixed variables are eliminated. Likewise, this paper utilises the principle of the repeat sales model to estimate the property tax capitalisation effect under the Korean taxation context ${ }^{6}$.

${ }^{5} I_{t}=\exp \left(\beta_{t}\right) \times 100$.

${ }^{6}$ Although this research uses appraisal prices, the principle of the analysis relies on the repeat sales model that use transaction data. 
When there are no property taxes, the hedonic price model can be specified like Equation (4).

$$
\hat{P}=\alpha_{0}+\sum_{k=1}^{K} \alpha_{k} X_{t}
$$

where, $\hat{P}$ is the housing price before imposing the property tax.

$X$ is attributes of the house.

$\alpha_{0}$ is an intercept.

$\alpha_{k}$ is a coefficient.

When the effective property tax rate is $\tau$, the amount of property taxes is $P \times \tau . P \times \tau$ should be divided by the discount rate $(r)$ in order to acquire the total present value of property taxes. When the property tax is in operation, the hedonic price model can be expressed like Equation (5) ${ }^{7}$.

$$
P_{t}=\sum_{k=1}^{K} \alpha_{k} X_{t}-\beta\left(\frac{T_{t-1}}{r}\right)
$$

In Equation (5), $T_{t-1} / r$ is a net present value of property tax payments and $\beta$ is a coefficient that indicates the capitalisation rate. If $\beta$ equals one, property taxes are fully capitalised. Housing prices decrease by the present value of increased property taxes. On the other hand, ifequals zero, housing prices do not change regardless of newly added property taxes. In Equation (5), the period of the left side - the housing price $(P)$ - is $t$ while, on one of the right side - the amount of property tax $(T)$ -is $t-1 . P_{t}$ is closely tied to $P_{t-1}$ as effective tax rates and the amount of total property taxes are decided by housing prices, causing an auto-correlation problem that creates difficulty in estimating by OLS. Due to the Korean taxation context discussed in the Section 2, one more step is required. In order to remove the auto-correlation problem, the repeat sales method is modified as suggested by McMillen (2003) and used by Kim \& Lee (2005). In the period $t+1$, housing prices including property taxes become Equation (6).

$$
P_{t+1}=\alpha_{t+1}+\sum_{k=1}^{K} \alpha_{k} X_{t}-\beta\left(\frac{T_{t}}{r}\right)
$$

If Equation (6) is subtracted from Equation (5), the attributes of the house are eliminated. It is possible when there have been no substantial physical changes to housing attributes between $t$ and $t+1$. Finally, Equation (7) can be reached to a simplified form to conduct a regression analysis.

$$
P_{t+1}-P_{t}=\gamma_{0}+\gamma_{1}\left(T_{t}-T_{t-1}\right)
$$

$\gamma_{0}$ is $\alpha_{t+1}-\alpha_{t}$, and this intercept signifies changes of hous-

${ }^{7}$ Theoretically, capitalisation takes place at the time of the announcement of the tax change. However, one year time lag is necessary given the policy context. Property taxation is complicated enough to recognise because they consist of different kinds of taxes in Korea. In addition, the amount of property taxes is billed to home owners in June and September whereas appraising is done in January and noticing, in April. Thus, this study assumes that property taxes in year thave an influence on housing prices in year $t+1$, taking a one-year time-lag in Equation (5). The assumption about the one-year time-lag is reasonable as far as processes of appraisal, notice, and billing are concerned.

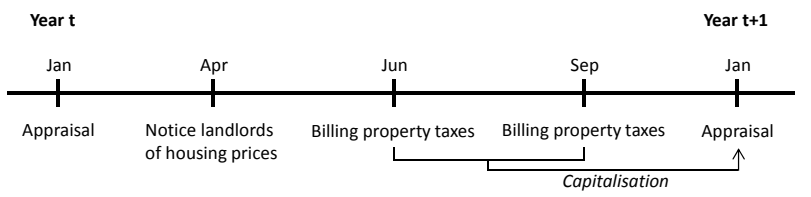

ing prices due to the socio-economic conditions such as income levels, the demand for or the supply of housing, public services and employment. These factors are not spatially specific, thus can be equally applied to all areas in Seoul. $\gamma_{1}$ is the coefficient that represents the change in housing prices caused by the changes of property taxes. $\gamma_{1}$ equals $-\beta / r$, therefore, $\beta$ is calculated by $-\gamma_{1} \times r$.

In addition to the changes in market trends such as the demand and the supply, local influences caused by location-specific changes in amenity, infrastructure, and accessibility, can differ between districts over the analysis period. For example, the construction of an outer circular highway around Seoul was completed in 2006. Due to the new highway, accessibility was improved in the northern part of Seoul, which influenced housing prices. Housing supply varies between districts. For example, while there was no new apartment construction in Nowon, 27,559 new apartments were built in Songpa in 2007-2008. Conditions of supply and demand in each region create a discrepancy in housing price movements. It is necessary to consider these effects are different in each district. Thus, district dummy variables are added to Equation (4) to measure the location-specific influence over time. For example, for Seochogu, only the Seochogu's district dummy variable equals one, otherwise zero. District dummy variables explain time-varying effects between districts.

\section{Result of Analysis}

As a result of a regression analysis ${ }^{8}$, almost all variables are statistically significant at the $95 \%$ confidence level (see Table 4). The intercept-17,537-plays an important role in interpreting the trend in the housing market. With taxation effects and location-specific differences controlled, the intercept explains that housing prices increased by 17,537 thousand WON on average between 2007 and 2008. When referring to the average housing price in 2007, the average change in housing prices over the one year was a $6.3 \%$ increase $(=17.537 / 279.04)$. This is attributable to the provision of public goods, macroeconomic factors, and the demand for and the supply of housing.

Only four district dummy variables are not significant at the $5 \%$ significance level, but two of them are statistically significant at the $90 \%$ confidence level (see Table 5) ${ }^{9}$. Two districts, Eunpyeong and Gwanak, show that the dummy variable is not significant at the $10 \%$ of the significance level. This is due to variations in housing prices from house to house in Eunpyeong and Gwanak are so large that the statistics cannot conclude that the change in housing prices is different from the base district, Gangnam. For example, there have been redevelopment projects, called New Town Development, in Eunpyeong, since 2002. Thus the infrastructure provided concentrated on specific areas. This caused larger variations in housing prices in Eunpyeong. Housing prices in the new residential development in Eunpyeong increased much more than outside of the develop-

${ }^{8}$ This model has $48.3 \%$ of explanatory power. The low R-square is the weakness of repeat sales model because the repeat sales model does not have other independent variables that can explain the variation in the dependent variable.

${ }^{9}$ The regression is based on housing prices changes from 2007 to 2008. Due to the one-year time-lag, changes from 2006 to 2007 were not analysed in this regression analysis. 
Table 4.

Descriptive statistics of dependent and independent variables.

\begin{tabular}{ccccc}
\hline Variables & Mean & $\begin{array}{c}\text { Standard } \\
\text { Deviation }\end{array}$ & Minimum & Maximum \\
\hline $\begin{array}{c}\text { Tax payment } \\
\text { (independent variable) } \\
T_{t}-T_{t-1}\end{array}$ & 163.7 & 502.0 & $-1,785.7$ & $13,819.2$ \\
$\begin{array}{c}\text { Housing price } \\
\text { (dependent variable) } \\
P_{t+1}-P_{t}\end{array}$ & 11,904 & 25,801 & $-376,000$ & 239,000 \\
\hline
\end{tabular}

Note: Unit is thousand WON.

Table 5.

Result of a regression analysis.

\begin{tabular}{|c|c|c|c|c|}
\hline & Coefficient & Standard Eerror & $\mathrm{t}$-value & $p$-value \\
\hline Intercept & 17537.0 & 475.5 & 36.88 & $<.0001$ \\
\hline$\Delta T$ & -21.9 & 0.2 & -94.70 & $<.0001$ \\
\hline Gangdong & -20226.0 & 647.7 & -31.23 & $<.0001$ \\
\hline Gangbuk & 19625.0 & 846.6 & 23.18 & $<.0001$ \\
\hline Gangseo & -15055.0 & 680.5 & -22.12 & $<.0001$ \\
\hline Gwanak & 354.5 & 753.9 & 0.47 & .6381 \\
\hline Gwangjin & -12842.0 & 886.5 & -14.49 & $<.0001$ \\
\hline Guro & 6217.5 & 656.3 & 9.47 & $<.0001$ \\
\hline Geumcheon & -2891.6 & 818.5 & -3.53 & .0004 \\
\hline Nowon & 6328.7 & 531.9 & 11.90 & $<.0001$ \\
\hline Dobong & 7193.4 & 607.1 & 11.85 & $<.0001$ \\
\hline Dongdaemun & 8000.8 & 740.9 & 10.80 & $<.0001$ \\
\hline Dongjak & 2530.7 & 771.5 & 3.28 & .0010 \\
\hline Mapo & -5103.7 & 810.4 & -6.30 & $<.0001$ \\
\hline Seodaemun & 3538.1 & 783.6 & 4.52 & $<.0001$ \\
\hline Seocho & -13922.0 & 724.6 & -19.21 & $<.0001$ \\
\hline Seongdong & -2322.8 & 700.2 & -3.32 & .0009 \\
\hline Seongbuk & 7708.3 & 690.7 & 11.16 & $<.0001$ \\
\hline Songpa & -24975.0 & 613.9 & -40.68 & $<.0001$ \\
\hline Yangcheon & -31276.0 & 684.4 & -45.70 & $<.0001$ \\
\hline Yeongdeungpo & 1195.8 & 691.5 & 1.73 & .0838 \\
\hline Yongsan & 31316.0 & 1023.7 & 30.59 & $<.0001$ \\
\hline Eunpyeong & 483.0 & 958.8 & 0.50 & .6144 \\
\hline Jongno & 8174.7 & 1490.7 & 5.48 & $<.0001$ \\
\hline Jung & -16302.0 & 1184.0 & -13.77 & $<.0001$ \\
\hline Jungnang & -1398.6 & 735.6 & -1.90 & .0573 \\
\hline
\end{tabular}

"Dependent variable: $P_{t+1}-P_{t} ;{ }^{* *}$ adj-R square: $0.4831 ;{ }^{* * *}$ Notes: The unit is thousand WON, and Gangnam is the basement of district-dummy-variables. ment area ${ }^{10}$. Yongsan has the highest dummy-variable coefficient. Yongsan is in the middle of the three central business districts in Seoul, but the quality of houses is in general not as good as other residential areas. Recently, there have been redevelopment projects all over the Yongsan area. The dummy variable reflects the effect of the projects on housing price changes in Yongsan. Yangcheon and Songpa show the biggest decrease in housing prices. These two districts including Gangnam belonged to the most expensive areas in Seoul. Housing prices on the expensive areas decreased the most between 2007 and 2008.

The coefficient $-\gamma_{1}$ is -21.868 . This figure represents that housing prices decreased by 21.868 thousand WON when the property tax increased by one thousand WON. If there was no change in property tax payments, housing prices would increase by 17,537 (the intercept, $\gamma_{0}$ ) thousand WON. Housing prices decreased by 17,515 WON $(17,537-21.868 \times 163.7)$ on average due to the increase in property taxes.

The property tax capitalisation rate, $\beta$ is estimated using estimated coefficient $-\gamma_{1}$. The capitalisation rate can be acquired by multiplying $-\gamma_{1}$ by the discount rate. The discount rate is an opportunity cost that the home-owners can accrue when they invest in other options instead of housing. Simply, the longterm interest rate could be used as the discount rate (DiPasquale \& Wheaton, 1996: p. 207). However, deciding on a discount rate has been problematic in estimating the property tax capitalisation rate (Yinger et al., 1988). Some studies adopt a nominal discount rate instead of a real discount rate and some use higher rates than the real rates, thus making the capitalisation rate higher. A real discount rate needs to be used and income tax on interest and tax deduction should be considered when measuring the real discount rate (Yinger et al., 1988). According to the Bank of Korea, the long-term interest rate was 3.98\% in 2006 and $4.47 \%$ in 2007 . The income tax rate on interest income was $15.4 \%$. Considering the income tax rate on the interest, the real discount rate becomes $3.37 \%$ and $3.78 \%$, respectively. Accordingly, the capitalisation rate of the property taxes becomes $73.7 \%$ and $82.8 \%$. Thus, it is reasonable to conclude that the degree of property tax capitalisation was somewhere between $73.7 \%$ and $82.8 \%$ (see Table 6). As studied by Yinger et al. (1988), the result shows partial capitalisation that means the effect could transfer to the future owner (Palmon \& Smith, 1998) or to tenants thus resulting in an increase in rents.

\section{Conclusion}

This paper focuses on the property tax capitalisation effect under a unique Korean taxation context. The model employed in this research is simple but based on reasonable assumption in which the time-fixed variables can be eliminated. While a conventional hedonic price model includes locational and structural variables, the modified repeat sales model utilises variations in property tax payments, which simplifies model specification. The model in this research used three years data on housing prices and tax payments.

Given these unique institutional circumstances, as a result of the analysis, the property tax capitalisation rate in Seoul was between $73.7 \%$ and $82.8 \%$ in the period $2007-8$. This is partial

${ }^{10}$ There are two residential new development plans in Eunpyeong. An increase in housing prices on average in the areas within the development is 11.2 (million WON) while outside of the development is 10.1 (million WON). This shows that there exists a heterogeneous housing market even in the same district. 
Table 6.

Interest rates and capitalisation rate.

\begin{tabular}{ccc}
\hline & 2006 & 2007 \\
\hline${ }^{+}$Long term interest rate (\%) & 3.98 & 4.47 \\
Discount rate (\%) & 3.37 & 3.78 \\
Capitalisation rate (\%) & 73.7 & 82.8 \\
\hline
\end{tabular}

${ }^{+}$The bank of Korea (http://ecos.bok.or.kr/).

capitalisation but larger than Yinger et al.'s estimation (1988). The inevitability of property taxes might result in higher property tax capitalisation. As there are few exceptions in implementing property taxation, home owners in Seoul are unable to avoid increased property taxes. Thus, home owners have to accept an increase in property taxes.

In terms of policy objectives, the increase in property tax rates is conducive to changes in housing prices and increases in public funds. However, there is a fundamental issue about the rationale for property taxes. The purpose of the property tax is to ensure public goods which enhance property values, not to depreciate home values as an intervention tool in the housing market. Bruekner (1979) suggested that an efficiency is in the point that a property tax locally financed supports house values sufficiently in that region. Although Korean property taxes finance public expenditure, it is difficult to regard that the Korean property taxation is efficient due to the lack of a close connection between property taxes and public expenditure. Equity concerns have been more emphasised than taxation efficiency in Korea.

This study contributes to evidence of property tax capitalisation in a different policy context using the principle of the repeat sales model. As a result of the analysis, it is obvious that additional property taxes are reflected in home values. Property tax capitalisation can be understood as a natural result in response to policy changes.

\section{Acknowlegements}

The early idea of this paper was presented at the 2009 Housing Researchers Conference, Sydney, Australia, in 2009.

\section{REFERENCES}

Bailey, M. J., Muth, R. F., \& Nourse, H. O. (1963). A regression method for real estate price index construction. American Statistical Association Journal, 58, 933-942. http://dx.doi.org/10.1080/01621459.1963.10480679

Bruekner, J. K. (1979). Property values, local public expenditure and economic efficiency. Journal of Public Economics, 11, 223-245. http://dx.doi.org/10.1016/0047-2727(79)90006-9

Case, K. E., \& Shiller, R. J. (1987). Prices of single family homes since 1970: New indexes for four cities. USA: Yale University.

Choi, S.-H., Ryu, K.-M., Lee, G.-W., \& Lee, C.-M. (2010). A repeat sales price indices for office market using transaction data. Journal of Korea Planners Association, 45, 119-131 (In Korean). http://dx.doi.org/10.5124/jkma.2010.53.2.119

Dipasquale, D., \& Wheaton, W. C. (1996). Urban economics and real estate markets. Englewood Cliffs, NJ: Prentice Hall.

Ha, S.-K. (2010). Housing, social capital and community development in Seoul. Cities, 27, s35-s42. http://dx.doi.org/10.1016/j.cities.2010.03.004

Jang, J.-W. (2010). A panorama of a housing market for 30 years. Seoul: Chaeknamu (In Korean).

Kim, J.-Y., \& Lee, C.-M. (2004). Dynamic Change of Spatial Structure in Seoul: 1993-2004. Journal of Korea Planners Association, 39, 191-205 (In Korean).

Kim, J.-Y., \& Lee, C.-M. (2005). Dynamics of amenity effects on housing price. Journal of Korea Planners Association, 40, 59-74 (In Korean).

Mcmillen, D. P. (2003). The return of centralization to Chicago: Using repeat sales to identify changes in house price distance gradients. Regional Science and Urban economics, 33, 287-304. http://dx.doi.org/10.1016/S0166-0462(02)00028-5

Mcmillen, D. P. (2008). Changes in the distribution of house prices over time: Structural characteristics, neighborhood, or coefficients? Journal of Urban Economics, 64, 573-589. http://dx.doi.org/10.1016/j.jue.2008.06.002

Palmon, O., \& Smith, B. A. (1998). evidence on property tax capitalization. Journal of Political economy, 106, 1099-1111. http://dx.doi.org/10.1086/250041

Rosen, H. S., \& Gayer, T. (2007). Public finance. New York: McGrow Hill.

Yinger, J., Bloom, H. S., Börsch-Supan, A., \& Ladd, H. F. (1988). Property Taxes and House Values: The Theory and Estimation of Intrajurisdictional Property Tax Capitalization. Boston: Academic Press. 
H. M. KIM ET AL.

Appendix. Summary of Statistics by Districts in Seoul

\begin{tabular}{|c|c|c|c|c|c|c|c|}
\hline \multirow{2}{*}{ District } & \multirow{2}{*}{ Area $\left(\mathrm{km}^{2}\right)$} & \multirow{2}{*}{ Population } & \multirow{2}{*}{$\begin{array}{c}\text { Density } \\
\text { (persons } / \mathrm{km}^{2} \text { ) }\end{array}$} & \multirow{2}{*}{ Sample } & \multicolumn{3}{|c|}{ Average appraisal housing price (thousand WON) } \\
\hline & & & & & 2006 & 2007 & 2008 \\
\hline Gangnam & 39.54 & 560,958 & 14,187 & 1737 & 456,353 & 603,216 & 604,914 \\
\hline Gangdong & 24.58 & 464,546 & 18,899 & 1694 & 267,385 & 336,663 & 330,941 \\
\hline Gangbuk & 23.60 & 345,478 & 14,639 & 698 & 149,592 & 178,074 & 214,552 \\
\hline Gangseo & 41.42 & 560,424 & 13,530 & 1420 & 153,425 & 208,951 & 209,827 \\
\hline Gwanak & 29.57 & 535,571 & 18,112 & 996 & 181,043 & 218,169 & 235,098 \\
\hline Gwangjin & 17.05 & 376,572 & 22,086 & 602 & 271,824 & 348,909 & 349,781 \\
\hline Guro & 20.11 & 420,542 & 20,912 & 1658 & 153,732 & 188,551 & 211,452 \\
\hline Geumcheon & 13.01 & 249,108 & 19,147 & 771 & 151,669 & 179,289 & 193,218 \\
\hline Nowon & 35.42 & 616,753 & 17,413 & 5780 & 132,584 & 165,231 & 188,325 \\
\hline Dobong & 20.70 & 375,975 & 18,163 & 2374 & 141,795 & 165,311 & 189,337 \\
\hline Dongdaemun & 14.20 & 376,421 & 26,509 & 1057 & 197,463 & 221,254 & 246,017 \\
\hline Dongjak & 16.35 & 405,967 & 24,830 & 916 & 234,609 & 301,467 & 319,546 \\
\hline Mapo & 23.87 & 392,650 & 16,450 & 787 & 237,512 & 298,539 & 308,995 \\
\hline Seodaemun & 17.61 & 348,575 & 19,794 & 881 & 186,579 & 210,430 & 230,711 \\
\hline Seocho & 47.00 & 405,969 & 8638 & 1055 & 482,405 & 622,950 & 608,045 \\
\hline Seongdong & 16.85 & 333,535 & 19,794 & 1272 & 251,875 & 302,894 & 316,216 \\
\hline Seongbuk & 24.57 & 469,973 & 19,128 & 1358 & 185,801 & 209,062 & 233,591 \\
\hline Songpa & 33.88 & 623,876 & 18,414 & 1971 & 382,054 & 485,901 & 468,718 \\
\hline Yangcheon & 17.40 & 503,650 & 28,945 & 1325 & 241,695 & 350,082 & 330,229 \\
\hline Yeongdeungpo & 24.57 & 408,178 & 16,613 & 1301 & 240,287 & 303,849 & 318,542 \\
\hline Yongsan & 21.87 & 235,832 & 10,783 & 405 & 400,306 & 530,141 & 564,346 \\
\hline Eunpyeong & 29.71 & 459,196 & 15,456 & 495 & 158,012 & 180,048 & 197,485 \\
\hline Jongno & 23.91 & 165,846 & 6936 & 172 & 197,849 & 224,000 & 248,343 \\
\hline Jung & 9.96 & 130,044 & 13,057 & 291 & 276,117 & 330,732 & 329,893 \\
\hline Jungnang & 18.50 & 427,071 & 23,085 & 1085 & 142,528 & 166,378 & 181,882 \\
\hline Total(Seoul) & 605.25 & $10,192,710$ & 16,840 & 32,101 & 222,375 & 279,042 & 290,946 \\
\hline
\end{tabular}

Note: For appraisal housing price and sample, the sample of this study; Source: Ministry of Land, Transport and Marine Affairs. 